of calcified cartilage together with somewhat porotic bone that causes these bones to be rather more brittle than usual. The contrast between the abnormal enchondral ossification and normal periosteal ossification has been demonstrated on a number of occasions in radiographs of the spine, where vertical sectors of vertebrae are formed by the enchondral and lateral sectors by the periosteal mechanism.

Since the underlying biochemical defect is in the organic matrix of the growth cartilage, this is unaffected by a diet severely restricted in calcium, although patients may suffer other metabolic disturbances as a result of the unbalanced diet.-I am, etc.,

United Kingdom Atomic Energy

K. Littie. Authority,
Wantage, Berks.

\section{Calcium Metabolism in Acromegaly}

SIR,-After reading the paper by Dr. A. Nadarajah and colleagues on calcium metabolism in acromegaly (28 December, p. 797), we reviewed the records of 29 acromegalics evaluated in our hospitals.

Twenty-two patients had serum calcium determinations at variable times before and after therapy (radiation, cryohypophysectomy, or surgical hypophysectomy). Of the 13 patients who had a mean serum calcium above $5 \mathrm{mEq} / 1$., all but one showed a decrease after therapy (Fig. 1). The decrease was greater than $0.2 \mathrm{mEq} / \mathrm{l}$.
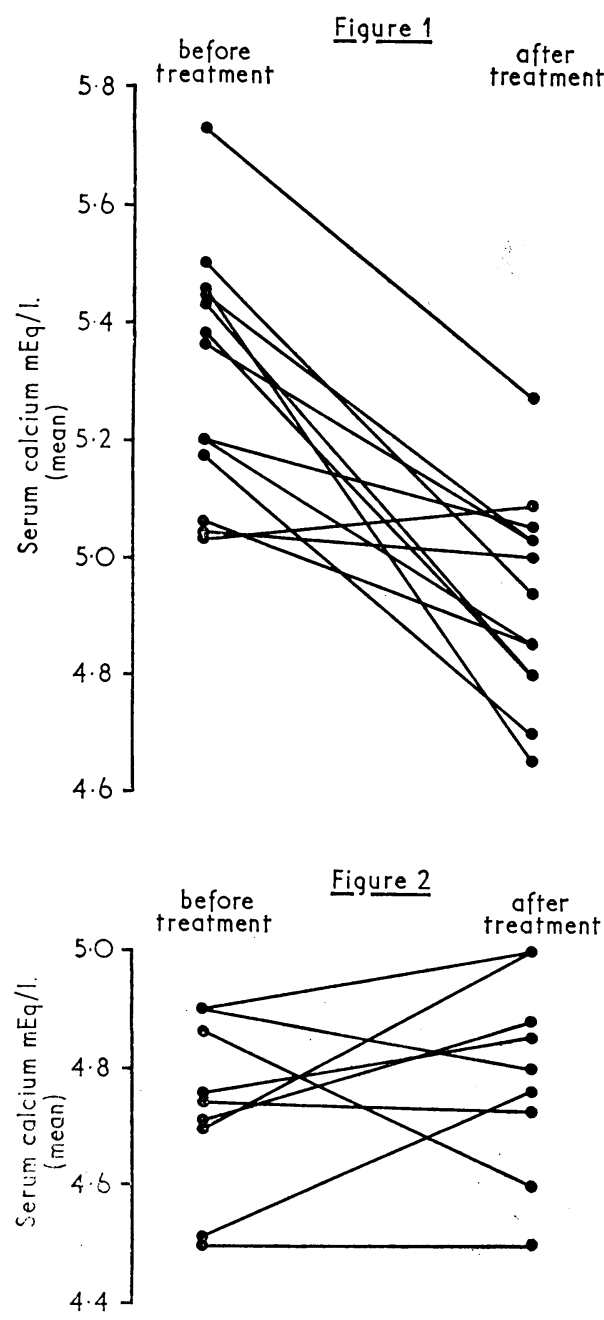

in all but two patients. The nine patients who had mean serum calciums less than $5 \mathrm{mEq} / 1$. showed no consistent change after therapy (Fig. 2). Serum phosphate showed no consistent pattern in either group. Because of the small number of patients in each group, no attempt was made to separate those that had a good response to treatment from those that did not respond. A rough estimate of the duration of acromegaly in all 29 patients was made by calculating the length of time any symptoms attributable to acromegaly were present prior to diagnosis. In the group with calcium above 5 $\mathrm{mEq} / \mathrm{l}$. the mean duration was 10 years and in the other it was 5.5 years. A non-paired $t$ test revealed $P<0.1$.

We feel that a likely explanation for these results is that excess growth hormone secretion in some patients causes parathyroid hyperplasia and possibly adenoma formation. Their glands secrete excess parathyroid hormone, resulting in high normal or even elevated serum calcium levels. Serum phosphate is variable because of the opposing effects of growth hormone and parathyroid hormone on renal phosphate excretion. Successful treatment of acromegaly may result in a fall in serum calcium levels which were high normal or greater before therapy, and may be another useful index of response to treatment. Duration of the disease along with severity probably are the main factors which influence calcium metabolism in acromegaly.-We are, etc.,

JOSIAH BROWN.

Division of Endocrinology,
Department of Medicine,

Department of Medicine,
Center for the Health Sciences,
University of California, U.S.A

FREDERICK R. SINGER.

Wadsworth Hospital

Los Angeles, California, U.S.A.

\section{Scientific Terminology}

SIR,-The undersigned members of the Council of the British Veterinary Zoological Society would like to make a plea to medical graduates and all other scientific workers to use in publications the internationally accepted scientific names of animals and plants. It is rarely essential to use these names, which are normally derived from Latin or Greek, when referring to man and domestic animals, but very important when referring to exotic laboratory animals and wild species.

Many medical and veterinary schools fail to make known to students the importance of the systematic scientific classification of animals and plants which was originally devised by Linnaeus, the famous Swedish naturalist, in 1758. The result is that most members of both professions are unaware of the principles and conventions of taxonomy. In publications they frequently fail to identify accurately the host and use only the common name such as " mouse," " bat," etc., although they may be scrupulous in quoting the scientific names of bacteria or other parasites infecting the animal. This use of the vernacular names only is to be deplored. The practice is unscientific and leads to a great deal of confusion, especially when foreigners endeavour to translate a language with which they are unfamiliar. Frequently there is more than one vernacular name for a, species, and of ten several species may share the same common name. The officers of this society would like to recommend that in all medical publications the scientific names of species or groups of animals should be given and included in the title wherever necessary.

In conclusion, we should like to draw the attention of the profession to the publication entitled International Code of Zoological Nomenclature Adopted by the XVth International Congress of Zoology, by Stoll et al. ${ }^{1}$ -We are, etc.,

$$
\begin{aligned}
& \text { I. F. KeYMER, } \\
& \text { V. J. A. Manton, } \\
& \begin{array}{c}
\text { Honorary Secretary, } \\
\text { British Veterinary Zoological Society. }
\end{array}
\end{aligned}
$$
Zoological Society of London,
Dunstable, Beds.

E. C. ApPleby.

D. K. BLACKMORE.

W. M. BRANCKER.

J. A. Dall.

O. Graham-Jones.

A. W. Messervy.

M. SENIOR.

REFERENCB Stoll, N. R., Dollfus, R. Ph., Forest, J, Riley,
N. D. S.abrosky, C. W ., W Wright, C. W., and
Melville, R. V., International Code of Zoological Nomenclature adopted by the XVth International Congress of Zoology, 1964 . London The International Commission of Zoological Nomenclature by the International Trust for

Abortion Act in Practice

SIR,-The Abortion Act 1967 is permissive in that what was previously an offence is no longer so when two registered medical practitioners in good faith decide that an abortion is justified according to the criteria laid down in the Act. It does not allow abortion, as your correspondent Dr. J. H. Hughes (8 March, p. 637) states, because women. "become pregnant at the wrong time." This interpretation may well be contrary to acting " in good faith," which, in the medical senseand it can only be in the medical sense-means a thorough appraisal of the situation, a knowledge of the literature on the subject, and an awareness of improvements in medical treatment and social measures which could influence the decision. It does not mean acting in wilful ignorance.

The Act does not give Dr. Hughes the right to castigate those psychiatrists who, acting "in good faith," are seriously in doubt as to whether an abortion is justified, and for good reasons know that support and treatment would be at least as effective as abortion in dealing with the problem be it social or medical. They have ample clinical evidence to support the " good faith" of their decisions and the law does not even require them to attest. It would be of great interest to see what factual evidence could be produced to support the many decisions to abort under the present Act. Those who advocate abortion and who ignore the massive evidence on what happens when the pregnancy is allowed to continue may not be challenged, because in this country a doctor's "good faith" is. rarely questioned. It could be questioned if doctors who perform the abortions have their services advertised, accept uncritically all the certificates sent to them, and charge fees. Similarly the doctor who signs the originat: 